\title{
Ortaokul Öğrencilerinin Fen Ve Teknoloji Dersi İle Fen Deneylerine Yönelik Tutumlarının Araştırılması (Muğla İli Örneği)
}

\author{
Şendil CAN \\ Ĕgitim Bilimleri Enstitüsü, Muğla Sıtkı Koçman Üniversitesi \\ csendil@mu.edu.tr \\ Emel DİKMENTEPE \\ Ĕgitim Bilimleri Enstitüsü, Muğla Sıtkı Koçman Üniversitesi \\ emeldikmentepe011@posta.mu.edu.tr
}

\section{$\ddot{O z e t}$}

Bu araştırmanın amacı ortaokul ögrrencilerinin Fen ve Teknoloji dersine yönelik tutumları ile fen deneylerine yönelik tutumlarına cinsiyet, sinıf düzeyi ve bilimsel yayın takip etme değișkenlerinin etkisini araştırmaktır. Araştırma 2013-2014 Ĕ̆itim-Öğretim yılı bahar döneminde Muğla İlinde Milli Ĕgitim Bakanlığı'na bağll özel bir ortaokulda öğrenim görmekte olan toplam 177 ögrrenci ile yürütülmüştür. Tarama yönteminde gerçekleştirilen bu araştırmada, Barmby, Kind, Jones ve Bush'un (2005) geliştirmiş olduğu Kaya ve Böyük'ün (2011) Türkçe'ye uyarladı̆̆ beşli likert tipinde 13 maddelik Fen ve Teknoloji dersi ile 8 maddelik fen deneylerine yönelik tutum ölçeği kullanılmıştır. Veriler SPSS 20.0 paket programiyla analiz edilmiştir. Araştırma sonunda ögrencilerin Fen ve Teknoloji dersi ile fen deneylerine yönelik tutumları arasında cinsiyete bağlı anlamlı bir farklılık olmadı̆̆ı, sinıf düzeyi açısından 5. Sinıf ögrrencilerinin lehinde anlamlı bir farklılığa neden olduğu ortaya çıkmıştır. Fen ve Teknoloji dersi ile fen deneylerine yönelik tutumları bilimsel yayın takip etmelerine bağlı olarak bilimsel yayın takip eden ögrencilerin lehine anlamlı bir farklılık gösterdiği tespit edilmiştir.

Anahtar Kelimeler: Fen ve Teknoloji Dersi, Fen Deneyleri, Tutum, Ortaokul Öğrencileri, Bilimsel Yayın

\section{Investigation Of Secondary School Students' Attitudes Towards Science And Technology Course And Science Experiments (Case Of Muğla)}

\begin{abstract}
The purpose of the present study is to investigate the effects of gender, grade level and the state of following scientific publications on secondary school students' attitudes towards Science and Technology course and science experiments. The study was conducted with 177 secondary school students attending a private school in the city of Muğla in the spring term of 2013-2014 school year. In the study employing the survey method, five-point Likert type 13-item scale of "Attitudes towards Science and Technology Course" developed by Barmby, Kind, Jones and Bush (2005) and adapted to Turkish by Kaya and Böyük
\end{abstract}


(2011) and 8-item scale of "Attitudes towards Science Experiments" were used to collect data. The collected data were analyzed through SPSS 20.0 program package. The findings of the study revealed that the students' attitudes towards Science and Technology course and science experiments did not significantly vary depending on gender variable; however, a significant difference was found in favor of the students fallowing scientific publications. In relation to grade level variable, a significant difference was found favoring 5 th grade students.

Key Words: Science and Technology course, Science experiments, Attitude, Secondary school students, Scientific publication

\section{Giriş}

21. Yüzyılın başıyla birlikte fen eğitiminde yeni bir reform çağına girilmekte ve bu noktada okul uygulamalarında öğrencilerin gerçek dünyayı gözlemledikleri ve etkileşim içinde oldukları deneyimler söz konusu olmaktadır (Hofstein ve Naaman, 2007). Bilim ve teknolojideki gelişmeler, hareketli bir yaşam şekli, hızlı ilerlemeler, yaşadığımız çağın gereklilikleri gibi etkenler ülkelerin yapısını değiştirdiği gibi, eğitimin ve eğitim sisteminin yapısını da etkilemektedir. Birçok ülkede fen eğitiminin özelliklerinden birisi de, öğrencilerin katılımıyla, gerçek nesne ve materyalleri gözlemlediği, içinde pratik çalışma barındıran nitelikte olmasıdır (Abrahams ve Millar, 2008). Gündelik yaşamla ilişkili olan Fen ve Teknoloji dersi deney, gözlem, hipotez kurma, sonuç çıkarma gibi becerileri kazandırma olanağından dolayı diğer derslerden ayrılmaktadır (Alkan ve Erdem, 2012).

Günümüzde günlük hayatlarındaki olayları araştıran, kritik ve analitik düşünebilen, karşılaştıkları problemleri bilimsel yollarla çözebilen, doğru karar verme becerileri gelişmiş, bilgili, bilinçli, bilimsel düşünebilen, bilimsel okuryazar bireylerin topluma kazandırılması amaçlanmaktadır (Ergin, 2005). Bilimsel yollardan edinilen bilgiler insanların doğal çevresini denetim altına almasını sağlamakla beraber, kendi yaşamını kolaylaştırmasında daha güvenli ve rahat yaşama yolunda kullanma yeteneğini sağlamaktadır (Doğan, Çakıroğlu, Bilican, Çavuş, 2009). Çocukların yaşadıkları çevreyi anlama, yorumlama, düzenlilik arama gibi güdüleri vardır. Bu yüzden bugünün fen eğitiminin amaçlarında çocukların, gençlerin sordukları soruları etkili bir şekilde cevaplamak ve sürekli değişen çevreye uyum sağlamalarında onlara yardımcı olmak yer almaktadır (Kaptan ve Korkmaz, 1999).

Fen deneyleri de fen eğitiminde öğrenme yaşantılarının gerekli ve ayrılmaz bir parçasıdır (Yıldız, Akpınar, Aydoğdu ve Ergin, 2006). İkinci Dünya savaşından sonra öğretmenler ve fen eğitimi araştırmacıları tarafından özel dikkat çeken laboratuar uygulamaları ile ihtiyaç duyulan şey, amaca uygun düşünmek ve önemli hedefleri sağlamak için farkındalık yaratmak olmuştur (Johnstone ve AlShuaili, 2001). Fen eğitiminin kazanımlarını gerçekleştirmede deneylerin kullanımı, öğrenmeyi kolaylaştırmayı mümkün kılmakta ve öğrencilerin konuyu daha somut olarak öğrenmelerini sağlamaktadır (Yaşar, 1998). Fen deneyleri aynı zamanda öğrencilerin bilimsel fenomenleri araştırmaları için küçük gruplar halinde çalıştığı öğrenme çevreleri ve eğitimi de sağlamaktadır (Hofstein, Nahum ve Shore 2001). Burada öğretmenlerin, deneylerin amaçlarına uygun olup olmadığını gözden geçirerek, uygun deneye karar vermeleri önemli olacaktır (Ergin, 2005).

Fen eğitiminde laboratuarlarda uygulamalı çalışmalar yer almadan öğrencilerin etkili öğrenmeleri de sınırlanacaktır. Çünkü fen eğitiminde fen deneyleri etkin bir role sahip olup, öğrencilerin anlamlı öğrenmelerini ve el becerilerini geliştirmeleri açısından yararlı olmaktadır (Aydoğdu ve Ergin, 2010; Hofstein ve Lunetta, 2004; Tobin, 1990). Fen eğitiminde deneye dayalı fen 
öğretimi öğrencilerin bilmediklerini keşfetmelerini ve öğrendikleri bilgilerin doğruluğunu test etmeleri açısından yararlı olmaktadır (Kaptan ve Korkmaz, 1999).

Laboratuar çalışmaları, fen öğrenme ve öğretme hedeflerini ayırmada ve tanımlamada benzersiz ve önemli katkı sağlanmaktadır (Hofstein ve Lunetta, 2004). Laboratuar çalışmaları öğrencilerin bireysel ve küçük gruplar halinde gerçekleştirildiği ya da çok büyük gruplar için gösteri deneyleri şeklinde tasarlandığı uygulamalardır. Böylece fen eğitiminde laboratuar çalışmalarının yer alması, öğrencilerin bilişsel, duyuşsal ve devinimsel hedeflere ulaşmasında kolaylık sağlayacaktır (Hofstein ve Naaman, 2007).

\subsection{Problem durumu}

$\mathrm{Bu}$ araştırmada ortaokul öğrencilerinin Fen ve Teknoloji dersi ile fen deneylerine yönelik tutumlarının cinsiyet, sınıf düzeyi ve bilimsel yayın takip etme değişkenleri açısından araştırılması amaçlanmıştır. Bu amaçlar doğrultusunda şu alt problemlere yanıt aranmıştır:

1) Öğrencilerin Fen ve Teknoloji dersi ile Fen Deneylerine yönelik tutumları hangi düzeydedir?

2) Öğrencilerin Fen ve Teknoloji dersine yönelik tutumlarının dağılımı nasıldır?

3) Öğrencilerin Fen ve Teknoloji dersine yönelik tutumları ile cinsiyet arasında anlamlı bir farklılık var midir?

4) Öğrencilerin Fen ve Teknoloji dersine yönelik tutumları sınıf düzeyine göre anlamlı bir farkl111k göstermekte midir?

5) Öğrencilerin Fen ve Teknoloji dersine yönelik tutumları ile bilimsel yayın takip etme durumları arasında anlamlı bir farklılık var mıdır?

6) Öğrencilerin Fen Deneylerine yönelik tutumlarının dağılımı nasıldır?

7) Öğrencilerin Fen Deneylerine yönelik tutumları ile cinsiyete arasında anlamlı bir farklılık var midır?

8) Öğrencilerin Fen Deneylerine yönelik tutumları, sınıf düzeyine göre anlamlı bir farklılık göstermekte midir?

9) Öğrencilerin Fen Deneylerine yönelik tutumları ile bilimsel yayın takip etme durumu arasında anlamlı bir farklılık var mıdır?

\subsection{Ilgili literatür}

Güven ve Selim (2014) bilimsel dergilerin Türkiye'deki yedinci sınıf öğrencilerinin hayatındaki yeri ve önemini, öğrencilerin Fen ve Teknoloji dersi, bilimsel okuryazarlık ve bilimsel dergiler arasındaki tutum ilişkisini araştırmıştır. Bunun için bilimsel dergilerin yedinci sınıf öğrencilerinin Fen ve Teknoloji dersi ve fen okuryazarlığı üzerindeki etkisini çeşitli değişkenlerle ilişkisini incelemişlerdir. Araştırmada öğrencilerin hangi bilimsel dergileri hangi sıklıkla takip ettikleri, ailelerinde hangi sıklıkla bu tür dergilerin okunduğu, cinsiyet ve velilerin eğitim durumları gibi demografik özellikleri belirleyen Öğrenci Tanıma Formu, Fen ve Teknoloji Dersi Tutum Ölçeği ve Bilimsel Okuryazarlık ölçeği kullanılmıştır. Bunun için araştırmacılar tarafından Türkiye'nin yedi farklı şehrinden örneklem alınmıştır. Sonuçlar, öğrencilerin babalarının eğitim seviyesi ile öğrencilerin Fen ve Teknoloji dersi ve fen okuryazarlığı arasında anlamlı bir farklılık olduğunu ortaya koymuştur. Bununla birlikte öğrencilerin fen okuryazarlığ seviyeleri ile tutumları arasında Fen ve Teknoloji dersine yönelik anlamlı bir ilişki bulunmuştur. Ek olarak bilimsel dergi okuyan öğrencilerin Fen ve Teknoloji dersine yönelik olumlu tutum içinde oldukları tespit edilmiştir. 
Nuhoğlu (2008) araştırmasıyla ortaokulda öğrenim gören 6., 7. ve 8. sınıf öğrencilerinin Fen ve Teknoloji dersine ve bu dersin kapsamında yapılan etkinliklere yönelik öğrencilerin tutumlarını tespit etmek amacıyla geçerli ve güvenilir bir tutum ölçeği geliştirmeyi amaçlamıştır. Araştırmacı ölçeğin örneklemini İstanbul il merkezinde bulunan üç okula uygulamıştır. Toplam 20 tutum maddesinden oluşan üçlü likert tipindeki ölçeğin Cronbach alfa güvenirlik katsayıs1 .87 olarak bulunmuştur. Araştırmacı geliştirdiği ölçekle öğretim programının içeriğine uygun olacak şekilde fene, teknolojiye, fen ve teknoloji dersinde yapılan etkinliklere yönelik tutum maddelerine yer vermiştir.

Pell ve Jarvis (2001), İngiltere'deki 16 okulda yaşları 5 ile 11 arasında değişen çocukların fen bilimleri hakkındaki tutumlarını ölçmek amacıyla geliştirdikleri ölçekle,

okulu sevmek, bağımsız araştırma, fene ilgi, fenin sosyal içeriği ve zor bir konu olarak fen başlıklarını içeren alt faktörlerden oluşan bir araştırma yapmıştır. Araştırmacı, araştırmasında kız ve erkek öğrencilerin tümünün fenin zor olduğu yönünde benzer bir tutuma sahip olduğu sonucuna ulaşmıştır.

Boone (1997) Çin'deki ortaokul öğrencilerinin Fen ve Teknoloji dersine yönelik tutumlarını cinsiyet faktörüne göre araştırmıştır. Araştırmacı çalışmasında, Çinli kız ve erkek öğrencilerin Fen ve Teknoloji dersine yönelik tutumlarını Fen ve Teknoloji konularını içeren likert tipinde ölçme aracı kullanarak belirlemiştir. Araştırmanın sonucunda, kız öğrencilerin Fen ve Teknoloji konularına yönelik tutumlarının daha olumlu düzeyde olduğu tespit edilmiştir.

\subsection{Araştırma yöntemi}

$\mathrm{Bu}$ araştırma tarama modelinde yürütülen betimsel bir araştırmadır.

\subsubsection{Evren ve örneklem}

Muğla İli ortaokullarında öğrenim görmekte olan öğrenciler araştırmanın evrenini oluşturmaktadır. Evrenin tamamına ulaşmanın zor olması gerekçesiyle örnekleme yoluna gidilmiştir. Bunun için de seçkisiz olmayan örnekleme yöntemlerinden tabakalı amaçlı örnekleme yöntemi kullanılmıştır. Araştırmanın örneklemini, 2013-2014 Eğitim-Öğretim yılı bahar döneminde Muğla İlinde Milli Eğitim Bakanlığı'na bağlı özel bir ortaokulda öğrenim gören 95'i 5. sinıf ve 82'si 8. sınıf olmak üzere toplam 177 ögrenci oluşturmaktadır.

\subsubsection{Veri toplama araçları}

Barmby ve diğerlerinin (2005) geliştirmiş olduğu beşli likert tipinde Fen ve Teknoloji dersi ile fen deneylerine yönelik tutum ölçeği kullanılmıştır. Bu iki ölçek, Kaya ve Böyük'ün (2011) Türkiye'ye uyarladığı, öğrencilerin Fen ve Teknoloji dersine yönelik tutumlarına ilişkin 13 tutum maddesi ve fen deneylerine yönelik tutumlarına ilişkin 8 tutum maddesi olmak üzere toplam 21 maddeden oluşmaktadır. Ölçekteki maddelerin puanlaması olumlu maddelerde "Kesinlikle katılmıyorum=1", "Katılmiyorum=2", "Kararsızım=3”, "Katıllyorum=4", "Kesinlikle katıllyorum $=5$ " şeklinde puanlanmış, olumsuz maddelerde ise puanlama tersine çevrilmiştir. Barmby ve diğerlerinin (2005) geliştirmiş olduğu ölçekteki güvenirlik katsayısı Cronbach alfa .76 olarak belirlenmiştir. $\mathrm{Bu}$ araştırmanın verileri ile hesaplanan Cronbach Alfa güvenirlik katsayısı ise .66 olarak bulunmuştur. 


\subsubsection{Verilerin analizi}

Verilerin analizinde SPSS 20.0 paket programı kullanılmıştır. Veriler Kaya ve Böyük'ün (2011) hazırlamış olduğu ölçek aralığı kullanılarak analiz edilmiştir. Aritmetik ortalamalar için 1.001.19 aralığı "Kesinlikle katılmıyorum", 1.80-2.59 aralığ1 "Katılmıyorum", 2.60-3.39 aralığ1 "Kararsızım”, 3.40-4.19 aralığ "Katıllyorum” ve 4.20-5.00 aralığ1 "Kesinlikle katıllyorum” şeklinde belirlenmiştir.

Fen ve Teknoloji dersine yönelik tutum ölçeği verileri normal dağılım gösterdiğinden (One Sample K-S; $\mathrm{p}=.113 ; \mathrm{p}>.05)$, ögrencilerin Fen ve Teknoloji dersine yönelik tutumlarının cinsiyet, sınıf düzeyi ve bilimsel yayın takip etme durumlarına göre farklılık gösterip göstermediği bağımsız gruplar t-testi ile analiz edilmiştir. Fen Deneylerine yönelik tutum ölçeği verileri normal dağılım göstermediğinden (One Sample K-S; $\mathrm{p}=0.00 ; \mathrm{p}<.05$ ), öğrencilerin Fen Deneylerine yönelik tutumlarının cinsiyet, sınıf düzeyi ve bilimsel yayın takip etme durumlarına göre farklılık gösterip göstermediği ise Mann-Whitney U testi ile analiz edilmiş̧tir.

\section{Bulgular}

Bu bölümde öğrencilerin Fen ve Teknoloji dersi ile Fen Deneylerine yönelik tutumları ve bu tutumların cinsiyet, sınıf düzeyi ve bilimsel yayın takip etme durumuna göre analiz edilmiş ve buna ait bulgular tablolar halinde verilerek yorumlanmıştır.

Tablo 1. Öğrencilerin Demografik Özelliklerine İlişkin Veriler

\begin{tabular}{lccc}
\hline \multirow{2}{*}{ DEĞíşKENLER } & Değişken Kategorileri & N & \% \\
\hline \multirow{2}{*}{ Cinsiyet } & Kız & 87 & 49.2 \\
& Erkek & 90 & 50.8 \\
\hline \multirow{2}{*}{ Sinıf düzeyi } & 5. sınıf & 95 & 53.7 \\
& 8. sinıf & 82 & 46.3 \\
\hline \multirow{2}{*}{ Bilimsel yayın takip etme } & Evet & 105 & 59.3 \\
& Hayır & 72 & 40.7 \\
\hline
\end{tabular}

Öğrencilerin cinsiyet, sınıf düzeyi ve bilimsel yayın takip etmelerine göre dağılımları Tablo 1'de verilmiştir. Tablo 1'e göre öğrencilerin 87'si (\% 49.2) kız, 90'1 (\% 50.8) erkektir. Sınıf düzeyine göre öğrencilerin 95 'inin (\% 53.7) beşinci sınıfta, 82'sinin (\% 46.3) sekizinci sınıfta öğrenim gördüğü belirlenmiştir. Öğrencilerin 105'i (\% 59.3) bilimsel yayın takip etmekte iken, 72'si (\% 40.7) bilimsel yayin takip etmemektedir.

\section{1. Öğrencilerin Fen ve Teknoloji Dersi ile Fen Deneylerine Yönelik Tutumlarının Düzeyi}


Tablo 2. Öğrencilerin Fen ve Teknoloji Dersi ile Fen Deneylerine Yönelik Tutumların Dağılımı

\begin{tabular}{lccccc}
\hline Tutum Ölçeği & N & En Düşük & En Yüksek & $\bar{X}$ & S \\
\hline Fen ve Teknoloji Dersi & 177 & 2.15 & 4 & 3.24 & .36 \\
Fen Deneyleri & 177 & 1.88 & 5 & 3.82 & .59 \\
\hline
\end{tabular}

Tablo 2'ye göre öğrencilerin, 13 tutum maddesinden oluşan Fen ve Teknoloji dersine yönelik tutumların aritmetik ortalamaları $(\overline{\mathrm{X}}=3.24), 2.60$ - 3.39 aralığına karşılık geldiğinden "Kararsız" tutum içinde oldukları; 8 tutum maddesinden oluşan fen deneylerine yönelik tutumların aritmetik ortalamaları ise $(\overline{\mathrm{X}}=3.82), 3.40-4.19$ aralığına karşılık geldiğinden "Katılıyorum" tutumuna sahip oldukları görülmektedir.

\section{2. Öğrencilerin Fen ve Teknoloji Dersine Yönelik Tutumlarına İlişkin Bulgular} verilmiştir.

Öğrencilerin 13 maddelik Fen ve Teknoloji dersine yönelik tutumlarının dağılımı Tablo 3‘te

Tablo 3. Öğrencilerin Fen ve Teknoloji Dersi Tutum Ölçeğine İlişkin Görüşlerinin Dağılımı

\begin{tabular}{|c|c|c|c|c|c|c|}
\hline Mac & leler & 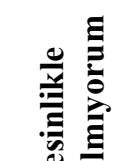 & 离 & 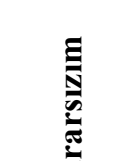 & $\stackrel{\Xi}{\Xi}$ & 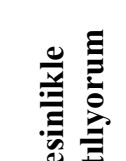 \\
\hline & & F (\%) & F (\%) & F (\%) & F (\%) & F (\%) \\
\hline 1. & $\begin{array}{l}\text { Fen ve Teknoloji dersinde ilginç şeyler } \\
\text { ögreniriz. }\end{array}$ & $4(2.3)$ & $6(3.4)$ & $11(6.2)$ & $51(28.8)$ & $105(59.3)$ \\
\hline 2. & $\begin{array}{l}\text { Fen ve Teknoloji dersini dört gözle } \\
\text { beklerim. }\end{array}$ & $6(3.4)$ & $10(5.6)$ & $33(18.6)$ & $62(35)$ & $66(37.3)$ \\
\hline 3. & Fen ve Teknoloji dersi heyecan vericidir. & $4(2.3)$ & $11(6.2)$ & $35(19.8)$ & $54(30.5)$ & $73(41.2)$ \\
\hline 4. & $\begin{array}{l}\text { Okulda daha fazla Fen ve Teknoloji } \\
\text { dersinin olmasinı isterim. }\end{array}$ & $11(6.2)$ & $22(12.4)$ & $64(36.2)$ & $35(19.8)$ & $45(25.4)$ \\
\hline 5. & $\begin{array}{l}\text { Okulda Fen ve Teknoloji dersini diğer } \\
\text { derslerden daha çok severim. }\end{array}$ & $19(10.7)$ & $27(15.3)$ & $72(40.7)$ & $27(15.3)$ & $32(18.1)$ \\
\hline 6. & Fen ve Teknoloji dersi sıkıcıdır. & $104(58.8)$ & $44(24.9)$ & $17(9.6)$ & $9(5.1)$ & $3(1.7)$ \\
\hline 7. & Fen ve Teknoloji dersi zordur. & $44(24.9)$ & $63(35.6)$ & $33(18.6)$ & $28(15.8)$ & $9(5.1)$ \\
\hline 8. & $\begin{array}{l}\text { Sadece Fen ve Teknoloji dersinde } \\
\text { başarısızım. }\end{array}$ & $90(50.8)$ & $40(22.6)$ & $32(18.1)$ & $3(1.7)$ & $12(6.8)$ \\
\hline 9. & $\begin{array}{l}\text { Fen ve Teknoloji dersinden yüksek notlar } \\
\text { alırım. }\end{array}$ & $3(1.7)$ & $16(9)$ & $26(14.7)$ & $65(36.7)$ & $67(37.9)$ \\
\hline 10. & Fen ve Teknoloji konularını kolayca & $5(2.8)$ & $16(9)$ & $41(23.2)$ & $57(32.2)$ & $58(32.8)$ \\
\hline
\end{tabular}


öğrenirim.

11. Fen ve Teknoloji dersi benim en başarılı olduğum derslerden biridir.

$\begin{array}{lrrrr}9(5.1) & 26(14.7) & 33(18.6) & 50(28.2) & 59(33.3) \\ 88(49.7) & 38(21.5) & 27(15.3) & 14(7.9) & 10(5.6) \\ 5(2.8) & 20(11.3) & 45(25.49 & 67(37.9) & 40(22.6)\end{array}$

Fen ve Teknoloji ödevlerimi yaparken

kendimi çaresiz hissederim.

Fen ve Teknoloji dersinde anlatılan her şeyi anlarım.

Öğrencilerin Fen ve Teknoloji dersine yönelik tutum ölçeğine ilişkin görüşleri Tablo 3'te verilmiştir. Öğrencilerin "Fen ve Teknoloji dersinde ilginç şeyler öğreniriz." şeklindeki 1. maddeye yönelik, en düşük oranda "kesinlikle katılmıyorum" (\% 2.3), en yüksek oranda "kesinlikle katılıyorum" (\% 59.3); "Fen ve Teknoloji dersini dört gözle beklerim." şeklindeki 2. maddeye yönelik en düşük oranda "kesinlikle katılmıyorum" (\% 3.4), en yüksek oranda " kesinlikle katıliyorum" (\% 37.3); "Fen ve Teknoloji dersi heyecan vericidir." şeklindeki 3. maddeye yönelik en düşük oranda "kesinlikle katılmıyorum" (\% 2.3), en yüksek oranda "kesinlikle katılıyorum" (\% 41.2); "Okulda daha fazla Fen ve Teknoloji dersinin olmasını isterim." şeklindeki 4. maddeye yönelik en düşük oranda "kesinlikle katılmıyorum" (\% 6.2), en yüksek oranda "kararsızım" (\% 36.2); "Okulda Fen ve Teknoloji dersini diğer derslerden daha çok severim." şeklindeki 5. maddeye yönelik en düşük oranda "kesinlikle katılmıyorum" (\% 10,7), en yüksek oranda "kararsızım" (\% 40.7); "Fen ve Teknoloji dersi sıkıcıdır." şeklindeki 6. maddeye yönelik en düşük oranda "kesinlikle katılıyorum" (\% 1.7), en yüksek oranda "kesinlikle katılmiyorum" (\% 58.8); "Fen ve Teknoloji dersi zordur." şeklindeki 7. maddeye yönelik en düşük oranda "kesinlikle katılıyorum" (\% 5.1), en yüksek oranda "katılmıyorum" (\% 35.6); "Sadece Fen ve Teknoloji dersinde başarısızım." şeklindeki 8. maddeye yönelik en düşük oranda "katılıyorum" (\% 1,7), en yüksek oranda "kesinlikle katılmıyorum" (\% 50.8); "Fen ve Teknoloji dersinden yüksek notlar alırım" şeklindeki 9. maddeye yönelik en düşük oranda "kesinlikle katılmıyorum" (\% 1.7), en yüksek oranda "kesinlikle katılıyorum" (\% 37.9); "Fen ve Teknoloji konularını kolayca öğrenirim." şeklindeki 10. maddeye yönelik en düşük oranda "kesinlikle katılmıyorum" (\% 2.8), en yüksek oranda "kesinlikle katılıyorum" (\% 32.8); "Fen ve Teknoloji dersi benim en başarılı olduğum derslerden biridir." șeklindeki 11. maddeye yönelik en düșük oranda "kesinlikle katılmıyorum" (\% 5.1), en yüksek oranda "kesinlikle katıllyorum" (\% 33.3); "Fen ve Teknoloji ödevlerimi yaparken kendimi çaresiz hissederim.” şeklindeki 12. maddeye yönelik en düşük oranda "kesinlikle katılıyorum" (\% 5.6), en yüksek oranda "kesinlikle katılmıyorum" (\% 49.7) ve son olarak "Fen ve Teknoloji dersinde anlatılan her şeyi anlarım." şeklindeki 13. maddeye yönelik en düşük oranda "kesinlikle katılmıyorum" (\% 2.8), en yüksek oranda "katılıyorum" (\% 37.9) tutumunda oldukları görülmektedir.

Öğrencilerin Fen ve Teknoloji dersine yönelik tutumlarının cinsiyete göre farklılık gösterip göstermediği t- testi ile analiz edilmiş ve bulgular Tablo 4'te verilmiştir.

Tablo 4. Öğrencilerin Fen ve Teknoloji Dersine Yönelik Tutumlarının Cinsiyete Göre T-Testi Sonuçları

\begin{tabular}{llccccc}
\hline Cinsiyet & N & $\bar{X}$ & S & sd & t & p \\
\hline Kiz & 87 & 3.27 & .38 & \multirow{2}{*}{175} & 1.24 & 0.21 \\
Erkek & 90 & 3.20 & .34 & & & \\
\hline
\end{tabular}

Tablo 4’te görüldüğü gibi öğrencilerin Fen ve Teknoloji dersine yönelik tutumları cinsiyete 
göre anlamlı bir farklılık göstermemektedir $\left[\mathrm{t}_{(175)}=1.24, \mathrm{p}>.05\right]$. Dolayısıyla öğrencilerin Fen ve Teknoloji dersine yönelik tutumlarında cinsiyetin etkili bir faktör olmadığ 1 söylenebilir. Bunun yanında kız öğrencilerin $(\overline{\mathrm{X}}=3.27)$ Fen ve Teknoloji dersine yönelik tutumlarının, erkek öğrencilere ( $\overline{\mathrm{X}}=3.20)$ göre daha olumlu olduğu görülmektedir.

Öğrencilerin Fen ve Teknoloji dersine yönelik tutumlarının sınıf düzeyine göre farklılık gösterip göstermediği t- testi ile analiz edilmiş ve bulgular Tablo 5 'te verilmiştir.

Tablo 5. Öğrencilerin Fen ve Teknoloji Dersine Yönelik Tutumlarının Sınıf Düzeyine Göre T-Testi Sonuçları

\begin{tabular}{lllllll}
\hline Sinıf düzeyi & $\mathbf{N}$ & $\bar{X}$ & S & sd & t & p \\
\hline 5.Sinıf & 95 & 3.30 & .33 & \multirow{2}{*}{175} & \multirow{2}{*}{2.58} & 0.01 \\
8.Sinıf & 82 & 3.16 & .38 & & & \\
\hline
\end{tabular}

Tablo 5'te görüldüğü gibi öğrencilerin sınıf düzeyine göre Fen ve Teknoloji dersine yönelik tutumları arasında anlamlı bir farklılık bulunmuştur $\left[\mathrm{t}_{(175)}=2.58, \mathrm{p}<.05\right]$. Tablo 5'e göre 5. sınıf öğrencilerinin $(\bar{X}=3.30)$ Fen ve Teknoloji dersine yönelik tutumlarının 8. Sinıf öğrencilerine $(\bar{X}$ $=3.16)$ göre daha olumlu olduğu görülmektedir.

Öğrencilerin Fen ve Teknoloji dersine yönelik tutumlarının bilimsel yayın takip etmelerine göre farklılık gösterip göstermediği t- testi ile analiz edilmiş ve bulgular Tablo 6'da verilmiştir.

Tablo 6. Öğrencilerin Fen ve Teknoloji Dersine Yönelik Tutumlarının Bilimsel Yayın Takip Etmelerine Göre T-Testi Sonuçları

\begin{tabular}{lcccccc}
\hline $\begin{array}{l}\text { Bilimsel Yayın } \\
\text { Takip Etme }\end{array}$ & $\mathbf{N}$ & $\bar{X}$ & S & sd & t & p \\
\hline Evet & 105 & 3.30 & .36 & 175 & 2.78 & .006 \\
Hayır & 72 & 3.15 & .35 & & \\
\hline
\end{tabular}

Tablo 6’ya göre öğrencilerin bilimsel yayın takip etme durumuna göre Fen ve Teknoloji dersine yönelik tutumları arasında anlamlı bir farklılık bulunmuştur $\left[\mathrm{t}_{(175)}=2.78 ; \mathrm{p}<.05\right]$. Tablo 6'dan bilimsel yayın takip eden öğrencilerin $(\bar{X}=3.30)$ Fen ve Teknoloji dersine yönelik tutumlarının, bilimsel yayın takip etmeyen öğrencilere $(\bar{X}=3.15)$ göre daha olumlu olduğu görülmektedir. Dolayısıyla, öğrencilerin bilimsel yayın takip etme durumu ile Fen ve Teknoloji dersine yönelik tutumları arasında bilimsel yayın takip eden öğrencilerin lehine anlamlı bir farklılık olduğu görülmektedir.

\section{3. Öğrencilerin Fen Deneylerine Yönelik Tutumlarına İlişkin Bulgular}


Öğrencilerin 8 maddelik Fen Deneylerine yönelik tutumlarına ilişkin görüşlerinin dağılımı Tablo 7`de verilmiştir.

Tablo 7. Öğrencilerin Fen Deneylerine Yönelik Tutum Ölçeğine İlişskin Görüşlerinin Dağılımı

\begin{tabular}{|c|c|c|c|c|c|c|}
\hline \multirow{2}{*}{\multicolumn{2}{|c|}{ Maddeler }} & \multirow{2}{*}{$\begin{array}{r} \\
\text { F (\%) } \\
\text { F }\end{array}$} & \multirow{2}{*}{ 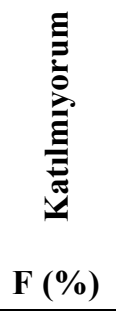 } & \multirow{2}{*}{ 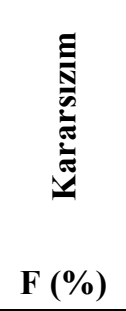 } & \multirow{2}{*}{ F (\%) } & \multirow{2}{*}{ 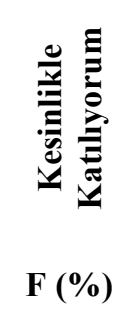 } \\
\hline & & & & & & \\
\hline 1. & Fen deneyleri heyecan vericidir. & $5(2.8)$ & $8(4.5)$ & $24(13.6)$ & $44(24.9)$ & $96(54.2)$ \\
\hline 2. & $\begin{array}{l}\text { Deney sonunda ne olacağını bilemediğiniz } \\
\text { için deneyleri severim. }\end{array}$ & $4(2.3)$ & $10(5.6)$ & $15(8.5)$ & $57(32.2)$ & $91(51.4)$ \\
\hline 3. & $\begin{array}{l}\text { Deneyler arkadaşlarımla ortak çalışma } \\
\text { fırsatı verdiği için faydalıdır. }\end{array}$ & $7(4)$ & $6(3.4)$ & $32(18.1)$ & $73(41.2)$ & $59(33.3)$ \\
\hline 4. & $\begin{array}{l}\text { Deneyleri kendi kendime karar verme } \\
\text { olanağı sağladığ } 1 \text { için severim. }\end{array}$ & $9(5.1)$ & $15(8.5)$ & $37(20.9)$ & $59(33.3)$ & $57(32.2)$ \\
\hline 5. & $\begin{array}{l}\text { Fen ve Teknoloji dersinde daha fazla deney } \\
\text { yapilmasını isterim. }\end{array}$ & $5(2.8)$ & $8(4.5)$ & $25(14.1)$ & $21(11.9)$ & $118(66.7)$ \\
\hline 6. & $\begin{array}{l}\text { Deneyler yapıldığı zaman Fen ve Teknoloji } \\
\text { derslerini daha iyi öğreniyoruz. }\end{array}$ & $3(1.7)$ & $10(5.6)$ & $22(12.4)$ & $49(27.7)$ & $93(52.5)$ \\
\hline 7. & $\begin{array}{l}\text { Fen ve Teknoloji dersinde deney yapmayı } \\
\text { dört gözle bekliyorum. }\end{array}$ & $8(4.5)$ & $9(5.1)$ & $26(14.7)$ & $44(24.9)$ & $90(50.8)$ \\
\hline 8. & $\begin{array}{l}\text { Fen ve Teknoloji dersinde deneyler } \\
\text { sikıcidır. }\end{array}$ & $118(66.7)$ & $30(16.9)$ & $19(10.7)$ & 7 (4) & $3(1.7)$ \\
\hline
\end{tabular}

Tablo 7'den öğrencilerin "Fen Deneyleri heyecan vericidir.” şeklindeki 1. maddeye yönelik en düşük oranda "kesinlikle katılmıyorum" (\% 2.8), en yüksek oranda "kesinlikle katılıyorum" (\% 54.2); "Deney sonunda ne olacağını bilemediğimiz için deneyleri severim." şeklindeki 2. maddeye yönelik en düşük oranda "kesinlikle katılmıyorum" (\% 2.3), en yüksek oranda "kesinlikle katıllyorum" (\% 51.4); "Deneyler arkadaşlarımla ortak çalışma fırsatı verdiği için faydalıdır." şeklindeki 3. maddeye yönelik en düşük oranda "katılmıyorum" (\% 3.4), en yüksek oranda "katıllyorum" (\% 41.2); "Deneyleri kendi kendime karar verme olanağı sağladığı için severim." şeklindeki 4. maddeye yönelik en düşük oranda "kesinlikle katılmıyorum" (\% 5.1), en yüksek oranda "katılıyorum" (\% 33.3); "Fen ve Teknoloji dersinde daha fazla deney yapılmasını isterim." şeklindeki 5. maddeye yönelik en düşük oranda "kesinlikle katılmıyorum" (\% 2.8), en yüksek oranda "kesinlikle katıllyorum" (\% 66.7); "Deneyler yapıldığ 1 zaman Fen ve Teknoloji derslerini daha iyi öğreniyoruz." şeklindeki 6. maddeye yönelik en düşük oranda "kesinlikle katılmıyorum" (\% 1.7), en yüksek oranda "kesinlikle katıllyorum" (\% 52.5); "Fen ve Teknoloji dersinde deney yapmayı dört gözle bekliyorum." şeklindeki 7. maddeye yönelik en düşük oranda "kesinlikle katılmıyorum" (\% 4.5), en yüksek oranda "kesinlikle katıllyorum" (\% 50.8) ve son olarak "Fen ve Teknoloji dersinde deneyler sıkıcıdır." şeklindeki 8. maddeye yönelik en düşük oranda "kesinlikle katılıyorum" (\% 1.7), en yüksek oranda "kesinlikle katılmıyorum" (\% 
66.7) tutumunda oldukları belirlenmiştir.

Öğrencilerin fen deneylerine yönelik tutumlarının cinsiyet, sınıf düzeyi ve bilimsel yayın takip etme durumuna göre farklılık gösterip göstermediği Mann Whitney-U testi ile analiz edilmiş ve bulgular Tablo 8, Tablo 9 ve Tablo 10'da verilmiştir.

Tablo 8. Öğrencilerin Fen Deneylerine Yönelik Tutumlarının Cinsiyete Göre Mann-Whitney U Testi Sonuçları

\begin{tabular}{llcccc}
\hline Cinsiyet & $\mathbf{N}$ & $\begin{array}{c}\text { SIra } \\
\text { Ortalaması }\end{array}$ & $\begin{array}{c}\text { Sıra } \\
\text { Toplamı }\end{array}$ & $\mathbf{U}$ & $\mathbf{p}$ \\
\hline K1z & 87 & 88.2 & 7673.5 & 3845.5 & .838 \\
Erkek & 90 & 89.7 & 8079.5 & & \\
\hline
\end{tabular}

Tablo 8'de görüldüğü gibi öğrencilerin fen deneylerine yönelik tutumları cinsiyete göre anlamlı bir farklılık göstermemektedir $(\mathrm{U}=3845.5, \mathrm{p}>.05)$. İstatistiksel olarak farklılık olmamasına karşın, sıra ortalamaları açısından erkek öğrencilerin (89.7) fen deneylerine yönelik tutumlarının kız öğrencilere (88.2) göre daha olumlu olduğu görülmüştür. Dolayısıyla öğrencilerin fen deneylerine yönelik tutumlarında cinsiyetin etkili bir faktör olmadığı söylenebilir.

Tablo 9. Öğrencilerin Fen Deneylerine Yönelik Tutumlarının Sınıf Düzeyine Göre Mann-Whitney U Testi Sonuçları

\begin{tabular}{lccccc}
\hline Sınıf Düzeyi & N & $\begin{array}{c}\text { Sira } \\
\text { Ortalaması }\end{array}$ & $\begin{array}{c}\text { Sira } \\
\text { Toplamı }\end{array}$ & U & p \\
\hline 5.Sinıf & 95 & 104.72 & 9948 & 2402 & .00 \\
8.Sinıf & 82 & 70.79 & 5805 & & \\
\hline
\end{tabular}

Tablo 9'dan öğrencilerin fen deneylerine yönelik tutumları sınıf düzeyine göre anlamlı bir farklılık göstermektedir $(\mathrm{U}=2402 ; \mathrm{p}<.05)$. Tablo 9'da sıra ortalamalarına göre, 5. sınıf öğrencilerinin fen deneylerine yönelik tutumlarının 8. Sınıf öğrencilerine göre daha olumlu olduğu görülmüştür. Dolayısıyla öğrencilerin sınıf düzeyine göre fen deneylerine yönelik tutumlarında 5. sınıf öğrencilerin lehine gerçekleşen anlamlı bir farklılık olduğu saptanmıştır.

Tablo 10. Öğrencilerin Fen Deneylerine Yönelik Tutumlarının Bilimsel Yayın Takip Etmelerine Göre MannWhitney U Testi Sonuçları

\begin{tabular}{lccccc}
\hline $\begin{array}{l}\text { Bilimsel Yayın } \\
\text { Takip Etme }\end{array}$ & $\mathbf{N}$ & $\begin{array}{c}\text { Sira } \\
\text { Ortalaması }\end{array}$ & $\begin{array}{c}\text { Sira } \\
\text { Toplamı }\end{array}$ & $\mathbf{U}$ & $\mathbf{p}$ \\
\hline Evet & 105 & 99.84 & 10483.5 & 2641.5 & .001 \\
Hayır & 72 & 73.19 & 5269.5 & & \\
\hline
\end{tabular}

Tablo 10'da görüldüğü gibi öğrencilerin bilimsel yayın takip etme durumuna göre fen deneylerine yönelik tutumları arasında anlamlı bir farklılık bulunmaktadır ( $U=2641.5, p<.05)$. Tablodan sıra ortalamalarına göre, bilimsel yayın takip eden öğrencilerin (99.84) fen deneylerine yönelik tutumlarının bilimsel yayın takip etmeyen öğrencilere (73.19) göre daha olumlu olduğu 
görülmüsşür. Dolayısıyla öğrencilerin fen deneylerine yönelik tutumlarında bilimsel yayın takip eden öğrencilerin lehine bir farklılık olduğu görülmektedir.

\section{Tartışma}

$\mathrm{Bu}$ araştırma ile öğrencilerin Fen ve Teknoloji dersi ile fen deneylerine yönelik tutumları cinsiyet, sınıf düzeyi ve bilimsel yayın takip etme durumu açısından araştırılmıştır. Öğrencilerin Fen ve Teknoloji dersine yönelik "kararsız" tutum sergiledikleri; fen deneylerine yönelik ise "katılıyorum" tutumuna sahip oldukları tespit edilmiştir. Dolayısıyla öğrencilerin fen deneylerine yönelik tutumlarının Fen ve Teknoloji dersine yönelik tutumlarından daha olumlu olduğu söylenebilir. Öğrencilerin fen deneylerine yönelik olumlu tutumları Aydoğdu ve Ergin'in (2010) araştırmasındaki sonuçlarla örtüşmektedir.

Öğrencilerin Fen ve Teknoloji dersine yönelik tutumları olumlu maddeler açısından değerlendirildiğinde, öğrencilerin en yüksek oranda olumlu tutum maddelerinden "Fen ve teknoloji dersinde ilginç şeyler ögreniriz.", "Fen ve teknoloji dersini dört gözle beklerim.", "Fen ve teknoloji dersi heyecan vericidir." "Fen ve teknoloji dersinden yüksek notlar alırım." , "Fen ve teknoloji konularını kolayca ögrenirim" ve "Fen ve teknoloji dersi benim en başarılı olduğum derslerden biridir." maddelerine yönelik "kesinlikle katılıyorum" şeklinde tutuma sahip oldukları tespit edilmiş̧ir. Bununla birlikte öğrencilerin en yüksek oranda "Fen ve teknoloji dersinde anlatılan her şeyi anlarım." maddesine yönelik "katıliyorum" tutumunda; "Okulda daha fazla fen ve teknoloji dersinin olmasın isterim." ve "Okulda fen ve teknoloji dersini diğer derslerden daha çok severim." maddelerine yönelik ise "kararsız" tutum içinde oldukları belirlenmiştir.

Öğrencilerin Fen ve Teknoloji dersine yönelik tutumları olumsuz maddeler açısından değerlendirildiğinde, öğrencilerin yüksek oranda "Fen ve teknoloji dersi sikıcıdır." , "Sadece fen ve teknoloji dersinde başarısızım." ve "Fen ve teknoloji ödevlerimi yaparken kendimi çaresiz hissederim." maddelerine yönelik "kesinlikle katılmıorum"; "Fen ve teknoloji dersi zordur." maddesine yönelik ise "katılmıyorum" tutumuna sahip oldukları tespit edilmiştir. Dolayısıyla öğrencilerin Fen ve Teknoloji dersiyle ilgili tutumlarının olumlu olduğu ve bu görüşlerin yukarıda belirtilen olumlu maddelere yönelik tutumlarını da desteklediği görülmektedir.

Öğrencilerin cinsiyete göre Fen ve Teknoloji dersine yönelik tutumları arasında farklılık bulunmamıştır. Bu sonuç Kaya ve Böyük'ün (2011) araştırmasındaki öğrencilerin cinsiyete göre Fen ve Teknoloji dersine yönelik tutumlarında anlamlı bir farklılık göstermediği sonucuyla paralellik göstermektedir. Buna karşın kız öğrencilerin Fen ve Teknoloji dersine yönelik tutumlarının daha olumlu olduğu görülmüştür. Bu sonuç ise Boone'un (1997) Çin'deki ortaokul öğrencilerinin Fen ve Teknoloji dersine yönelik tutumlarında kız öğrencilerin Fen ve Teknoloji konularına yönelik tutumlarının daha olumlu düzeyde olduğu bulgusuyla örtüşmektedir. Bunun yanında Pell ve Jarvis (2001) İngiltere'deki 16 okulda yaşları 5 ile 11 arasında değişen çocukların fen bilimleri hakkındaki tutumlarını ölçmek amacıyla uyguladıkları ölçekte kız ve erkek öğrencilerin her ikisinin de fene yönelik benzer bir tutuma sahip olduğu sonucuna ulaşmışlardır.

Öğrencilerin, Fen ve Teknoloji dersine yönelik tutumları sınıf düzeyine göre anlamlı bir farklılık gösterdiği tespit edilmiştir. Bu farklılık da 5. sınıf öğrencilerinin lehine bulunmuştur. Bu durum, 8. sınıfta öğrenim görmekte olan öğrencilerin ortaöğretime geçiş sınavına hazırlanmalarından kaynaklandığı söylenebilir. Literatürde farklı sonuçların elde edildiği çalışmalar da mevcuttur. 
Örneğin Kaya ve Böyük'ün (2011) araştırmasında, sınıf düzeyi değişkenine göre 8. sınıf öğrencilerinin Fen ve Teknoloji dersine yönelik tutumları diğer sınıflarda öğrenim gören öğrencilerden daha olumlu olduğu ortaya çıkmıştır.

Öğrencilerin bilimsel yayın takip etme değişkenine göre Fen ve Teknoloji dersine yönelik tutumları arasında anlamlı bir farklılık bulunmuştur. Bu farklılık da bilimsel yayın takip eden öğrencilerin lehine gerçekleşen anlamlı bir farklılıktır. Bu sonuç Güven ve Selim'in (2014) yedinci sınıfta öğrenim görmekte olan öğrencilerle yaptığı araştırmasında bilimsel dergi okuyan öğrencilerin Fen ve Teknoloji dersine yönelik olumlu tutum içinde oldukları sonucunu desteklemektedir.

Öğrencilerin fen deneylerine yönelik tutumları değerlendirildiğinde öğrencilerin yüksek oranda olumlu tutum maddelerinden "Fen deneyleri heyecan vericidir." , "Deney sonunda ne olacă̆ını bilemediğiniz için deneyleri severim." " "Fen ve teknoloji dersinde daha fazla deney yapılmasını isterim." , "Deneyler yapıldı̆̆ zaman fen ve teknoloji derslerini daha iyi ögreniyoruz." ve "Fen ve teknoloji dersinde deney yapmayı dört gözle bekliyorum." maddelerine yönelik "kesinlikle katılıyorum" şeklinde tutuma sahip oldukları; "Deneyler arkadaşlarımla ortak çalışma firsatı verdiği için faydalıdır." ve "Deneyleri kendi kendime karar verme olanağ sağladiğı için severim." maddelerine yönelik ise "katılıyorum" şeklinde tutum sergiledikleri tespit edilmiştir. Öğrencilerin "Fen ve teknoloji dersinde deneyler sıkıcıdır." şeklinde ifade edilen olumsuz tutum maddesi için ise "kesinlikle katılmıyorum" görüşünü belirttikleri dolayısıyla yukarıdaki olumlu tutum ifadelerini de destekledikleri görülmüştür.

Öğrencilerin fen deneylerine yönelik tutumlarında cinsiyet etkili bir faktör olmamıştır. Elde edilen bu bulgu Yeşilyurt, Kurt ve Temur'un (2005) araştırma sonuçlarıyla örtüşmektedir.

Öğrencilerin sınıf düzeyi değişkenine göre fen deneylerine yönelik tutumları arasında anlamlı bir farklılık bulunmaktadır. Elde edilen bulgulardan 5. sınıf öğrencilerinin fen deneylerine yönelik tutumlarının daha olumlu olduğu tespit edilmiştir. Kaya ve Böyük'ün (2011) elde ettiği bulgularda ise öğrencilerin sınıf düzeyine göre fen deneylerine yönelik tutumları arasında anlamlı bir farklılık olmadığ1 sonucuna varılmıştır. Bozdoğan ve Yalçın'ın (2005) Kırşehir il merkezindeki 6., 7. ve 8. sınıfta öğrenim görmekte olan ögrencilerin Fen ve Teknoloji dersindeki fizik konularına yönelik tutumlarını araştırdığı çalışmasında sınıf düzeyi arttıkça fen deneylerine yönelik tutumlarında azalma olduğunu belirtmiştir. Dolayısıyla bu araştırmanın sonucu çalışma bulgularımızla paralellik göstermektedir.

Öğrencilerin bilimsel yayın takip etme değişkenine göre fen deneylerine yönelik tutumları arasında anlamlı bir farklılık elde edilmiştir. Elde edilen bulgulara göre bilimsel yayın takip eden öğrencilerin fen deneylerine yönelik tutumlarının daha olumlu olduğu ve bilimsel bir bakış açısı kazanmalarının fen deneylerine yönelik tutumları üzerinde olumlu bir etki yarattı̆̆ söylenebilir.

\section{Sonuç ve Öneriler}

Araştırma bulgularından elde edilen sonuçlar aşağıda verilmiştir:

- Fen ve Teknoloji dersine yönelik tutumlarının "kararsız", fen deneylerine yönelik tutumlarının ise "katılıyorum" tutumunda olduğu tespit edilmiştir. Özellikle öğrencilerin fen deneylerine yönelik tutumlarının genel olarak olumlu olduğu sonucuna ulaşılmıştır. 
- Fen ve Teknoloji dersi ile fen deneylerine yönelik tutumlarının cinsiyete göre değişmediği belirlenmiştir.

- Fen ve Teknoloji dersi ile fen deneylerine yönelik tutumlarının sınıf düzeyine göre farklılık gösterdiği, bu farklılığın da 5. sınıf öğrencilerinin lehine olduğu sonucuna ulaşılmıştır.

- Fen ve Teknoloji dersi ile fen deneylerine yönelik tutumlarının bilimsel yayın takip etme durumuna bağlı olarak değiştiği ve bilimsel yayın takip eden öğrencilerin tutumlarının daha olumlu olduğu ortaya çıkmıştır.

Elde edilen sonuçlar ışı̆̆ında şu öneriler getirilebilir:

- 8. Sınıfta öğrenim görmekte olan öğrencilerin Fen ve Teknoloji dersi ile fen deneylerine yönelik daha olumlu tutum geliştirebilmeleri için Fen ve Teknoloji dersi ile ilgili eğlenceli aktivitelere yer verilebilir.

- Bilimsel yayın takip etmeyen öğrenciler, Fen ve Teknoloji dersine yönelik tutumlarının artması açısından bilimsel yayın takip etmeleri konusunda yönlendirilebilir.

- Araştırma, farklı değişkenler ve farklı eğitim kurumları açısından geliştirilerek konuya farklı boyutlardan bakma imkânı sağlanabilir.

\section{Kaynakça}

Abrahams, I. ve Millar, R. (2008). Does practical work really work? A study of the effectiveness of practical work as a teaching and learning method in school science. International Journal of Science Education, 30 (14), 1945-1969.

Alkan, F. ve Erdem, E. (2012). Laboratuar becerilerine yönelik tutum ölçeği geliştirme çalışması. Hacettepe Üniversitesi Eğitim Fakültesi Dergisi, Özel Sayl:1, 22-31, 2012.

Aydoğdu, B. ve Ergin, Ö. (2010). Fen ve teknoloji dersinde kullantlan farkl deney tekniklerinin ögrencilerin ögrenme yaklaşımlarına etkileri. In International Conference on New Trends in Education and Their Implications, pp. 11-13, 2010, Kasim.

Barmby, P., Kind. P. M., Jones, K. ve Bush, N. (2005). Evaluation of lab in a lorry, Final Report Durham University. CEM Centre of School and Education, 2005.

Boone, W. J. (1997). Science attitudes of selected middle school students in china: a preliminary investigation of similarities and differences as a function of gender. School Science and Mathematics, 97 (2): 96-103.

Bozdoğan A. E. ve Yalçın N. (2005). İlköğretim 6., 7. ve 8. sınıf öğrencilerinin Fen Bilgisi derslerindeki fizik konularına karşı tutumları. Gazi Üniversitesi Kırşehir Eğitim Fakültesi Dergisi, 6 (1), 241-247, 2005.

Doğan, N., Çakıroğlu, J., Bilican, K. ve Çavuş, S. (2009). Bilimin doğası ve ögrretimi. Pegem Akademi, Ankara. 
Ergin, Ö. (2005). Kuramdan uygulamaya deney yoluyla fen öğretimi. Dinazor Kitabevi, İzmir.

Güven, İ. ve Selim G. (2014). The Place of the scientific magazines in the life of 7th grade students: the relationship between the attitude towards science and technology lesson, the scientific literacy and scientific magazines. International J. Soc. Sci. \& Education 2014 Vol.4 Issue 3, ISSN: 2223-4934 E and 2227-393X Print

Hofstein, A., Nahum, T. L. ve Shore, R. (2001). Assessment of the learning environment of inquirytype laboratories in high school chemistry. Learning Environments Research, 4 (2), 193-207.

Hofstein, A., ve Lunetta, V. N. (2004). The Laboratory in science education: foundations for the twenty-first century. Science Education, 88(1), 28-54.

Hofstein, A. ve Naaman R. M., (2007). The Laboratory in science education: the state of the art. Chemistry Education Research and Practice, 8 (2), 105-107, 2007.

Johnstone, A. H. ve Al-Shuaili, A. (2001). Learning in the laboratory; some thoughts from the literature. University Chemistry Education, 5 (2), 42-51.

Kaptan, F. ve Korkmaz, H. (1999). İlkögrretimde Etkili Öğretme ve Öğrenme Öğretmen El Kitabı. Modül 7.

Kaya, H. ve Böyük, U. (2011). İlköğretim 2. kademe öğrencilerinin fen ve teknoloji dersine ve fen deneylerine karşı tutumları. Türk Bilim Araştırma Vakfı, TUBAV Bilim Dergisi, Cilt: 4, Sayı: 2, Sayfa: 120-130, Erciyes Üniversitesi.

Nuhoğlu, H. (2008). İlköğretim fen ve teknoloji dersine yönelik bir tutum ölçeğinin geliştirilmesi. Ilköğretim Online, 7(3), 627-639, 2008.

Pell, T. ve Jarvis, T. (2001). Developing attitude to science scales for use with children of ages from 5 to 11. Internatial Journal of Science Education, 23 (8): 847-862.

Tobin, K. (1990). Research on Science Laboratory Activities in Pursuit of Better Questions and Answers to Improve Learning. Florida State University, School Science and Mathematics, Volume 90, May/June.

Yaşar, Ş. (1998). Fen Bilgisi öğretiminde kullanılan strateji, yöntem ve teknikler. Anadolu Üniversitesi, Açıköğretim Yayınları.

Yeşilyurt M., Kurt T. ve Temur A. (2005). İlköğretim fen laboratuarı için tutum anketi geliştirilmesi ve uygulanması. Pamukkale Üniversitesi Eğitim Fakültesi Dergisi, 17, 2005.

Yıldız, E., Akpınar, E., Aydoğdu, B. ve Ergin, Ö. (2006). Fen Bilgisi Öğretmenlerinin Fen Deneylerinin Amaçlarına Yönelik Tutumları. Türk Fen Eğitimi Dergisi, 3, 2, 2006, İzmir. 
MSKU Ĕ̈itim Fakültesi Dergisi MSKU Journal of Education

ISSN 2148-6999 Cilt-Volume 2, Sayl- Number 1, 2015

Doç. Dr., Muğla Sttkı Koçman Üniversitesi, Eğitim Bilimleri Enstitüsü,

Şendil CAN

E-mail: csendil@mu.edu.tr

Emel

Doktora Öğrencisi, Muğla Sitkı Koçman Üniversitesi, Ĕgitim Bilimleri

DIKKMENTEPE

Enstitüsü,

E-mail:emeldikmentepe011@posta.mu.edu.tr 